\title{
Flood prevention and mitigation at large rivers
}

\author{
Helmut Habersack • Daniel Haspel • Bernhard Schober
}

Received: 5 June 2014/ Accepted: 27 July 2014/Published online: 29 August 2014

(C) Springer Science+Business Media Dordrecht 2014

The pressures and impacts on the World's Large Rivers have increased greatly in recent years, as a consequence of their exploitation to meet various human needs. Large rivers are particularly exposed to problems of multiple uses, often with conflicting aims. Worldwide river systems are altered by land use changes and cutting off floodplains leading to the loss of retention storage capacity and therefore to increased peak discharges and reduced translation time of the flood wave downstream. This results in far-reaching problems further downstream like increased flood risk due to higher peak discharges and changed local hydraulic parameters like higher water levels as well as difficulties in delivery of flood warnings due to reduced lead time. These challenges point also to the need for more integrated management approaches, consideration of catchment and river interactions (also in regard to water quality preservation), emphasizing flood-adapted land use management, spatial planning and awareness of all involved stakeholders.

At the global scale, there is currently no overview assessment of the current status of the world's large rivers, the conflicting demands on such rivers, and likely future anthropogenic impacts, as well as the potential for restoration, improvements in integrated management and the associated problems caused by their multiple uses. The International Conference on "The Status and Future of the World's Large Rivers" and this Special Issue in Natural Hazards on Flood prevention and mitigation at large rivers aims to provide a global forum for a wide-ranging discussion of key issues related to research on large rivers

\footnotetext{
H. Habersack $(\bowtie) \cdot$ D. Haspel · B. Schober

Christian Doppler Laboratory for Advanced Methods in River Monitoring, Modelling and Engineering, Department for Water - Atmosphere - Environment, Institute for Water Management, Hydrology and Hydraulic Engineering, University of Natural Resources and Life Sciences, Muthgasse 107,

1190 Vienna, Austria

e-mail: helmut.habersack@boku.ac.at

D. Haspel

e-mail: daniel.haspel@boku.ac.at

B. Schober

e-mail: bernhard.schober@boku.ac.at
} 
and to their effective and sustainable management, involving both scientists and decision makers. The sequence of papers in the Special Issue highlights the current situation in different catchments along the Danube and its tributaries with regard to (1) flood protection by enforcing natural retention processes in order to reduce the negative effects of floods, (2) society's ability to coexist with floods, (3) the comparison of retention potential for the current and a non-anthropogenic influenced (historical) stage and (4) quantitative assessment of environmental impact and associated risk of the economic activities with regard to water quality management. Beside seven other Special Issues in SCI journals, this Special Issue is an outcome of the first International Conference on the Status and Future of the World's Large Rivers held from 11 to 14 April 2011 in Vienna (http://worldslargerivers. boku.ac.at/wlr/). The second conference took place in Manaus, Brazil, from 21 to 25 July 2014.

The Special Issue presents five articles that deal with the following topics:

The paper of Habersack et al. (2013) investigates the role of floodplains within an integrated flood risk management. Hydrological, hydraulic, ecological and sociological parameters are used to determine floodplain efficiency in an interdisciplinary approach. The results are finally assembled in the floodplain evaluation matrix (FEM) which evaluates floodplains which are important for flood risk reduction and hence should be preserved by all means.

Schober et al. (2013) applied this floodplain evaluation matrix (FEM) to the Austrian Danube along its $350 \mathrm{~km}$ length. Hydrological and hydraulic parameters were assessed for the major floodplains in order to determine their efficiency in the context of integrated flood risk management. The results, e.g. a ranking of floodplains according to their hydrological efficiency, were also linked to the morphological characteristics of the floodplains which might serve as basic data for future flood risk management strategies.

Skublics and Rutschmann (2014) investigated the retention potential of a 270-km-long section of the Bavarian Danube. Using 2d-hydrodynamic models, they simulated the flooding of the river prior to the implementation of any river regulation measures, i.e. a state at around 1800, and compared the results with the present state. Surprisingly, even though the retention volume during the historical state was much larger compared with the present, only minimal or even negative effects on the damping of flood peaks could be detected for some cross-sections.

Ionuş et al. (2013) assessed flood-prone stripes along the Motru and Danube River in Romania. Society's ability to coexist with floods, rather than be protected from them, was investigated. In this context, the authors showed that the exposed elements within the study area hold a poor coping capacity against extreme hydrometeorological events.

Teodosiu et al. (2013) present the development and implementation of a methodology for the quantitative assessment of environmental impact and associated risks of the economic activities at the Prut River basin in Romania. The authors analysed several water quality indicators monthly and revealed that there are consistent environmental impacts and risks within the Prut River basin, these being mainly produced by industry.

Worldwide, about one-third of the total number of damaging events as well as one-third of economic damages (destruction of buildings, infrastructure, crops, etc.) is caused by the consequences of catastrophic flooding, and more than half of all persons killed by natural disasters over the last decades lost their lives in flood events (Koirala 2011). International studies highlighted that the number of floods in Europe has dramatically increased at the beginning of the new millennium, coupled with a rise in the amount of damages and economical losses (Barredo 2007). Therefore, thorough research on the functioning of riverine systems is essential as basis for an integrated flood risk management and water 
quality management in order to deal with natural hazards along rivers. The presented papers for this Special Issue give an insight on those river functions and propose management strategies as well as future research demand.

\section{References}

Barredo JI (2007) Major flood disasters in Europe: 1950-2005. J Nat Hazards 42:125-148

Habersack H, Schober B, Hauer C (2013) Floodplain evaluation matrix (FEM): an interdisciplinary method for evaluating river floodplains in the context of integrated flood risk management. Nat Hazards 1-28. doi:10.1007/s11069-013-0842-4

Ionuş O, Licurici M, Pătroescu M, Boengiu S (2013) Assessment of flood-prone stripes within the Danube drainage area in the South-West Oltenia Development Region, Romania. Nat Hazards 1-20. doi:10. 1007/s11069-013-0720-0

Koirala S (2011) Some flood damage estimate of the world. UNESCO-IHE Flood Management Education Platform. http://www.unesco-ihe.org/Flood-Management-Education-Platform. Accessed Oct 2011

Schober B, Hauer C, Habersack H (2013) A novel assessment of the role of Danube floodplains in flood hazard reduction (FEM method). Nat Hazards 1-18. doi:10.1007/s11069-013-0880-y

Skublics D, Rutschmann P (2014) Progress in natural flood retention at the Bavarian Danube. Nat Hazards 1-17. doi:10.1007/s11069-014-1148-x

Teodosiu C, Robu B, Cojocariu C, Barjoveanu G (2013) Environmental impact and risk quantification based on selected water quality indicators. Nat Hazards 1-17. doi:10.1007/s11069-013-0637-7 